\title{
Relaxation Responses of Trigonal Smooth Muscle from Rabbit by Alpha - Adrenoceptor Antagonists Alfuzosin, Doxazosin and Tamsulosin
}

\author{
A. KARADENIZ' ${ }^{1}$ İ. PİŞKIN ${ }^{2}$, D. EŞSİZ ${ }^{3}$, L. ALTINTAŞ ${ }^{4}$ \\ ${ }^{1}$ University of Atatürk, Faculty of Veterinary Medicine, Department of Physiology, Erzurum, Turkey \\ ${ }^{2}$ University of Ankara, Faculty of Veterinary Medicine, Department of Physiology, Ankara, Turkey \\ ${ }^{3}$ University of Kafkas, Faculty of Veterinary Medicine, Department of Pharmacology and Toxicology, \\ Kars, Turkey \\ ${ }^{4}$ University of Ankara, Faculty of Veterinary Medicine, Department of Pharmacology and Toxicology, \\ Ankara, Turkey
}

Received April 9, 2007

Accepted December 19, 2007

\begin{abstract}
Karadeniz A., İ. Pişkin, D. Eşsiz, L. Altintaş: Relaxation Responses of Trigonal Smooth Muscle from Rabbit by Alpha - Adrenoceptor Antagonists Alfuzosin, Doxazosin and Tamsulosin. Acta Vet. Brno 2008, 77: 81-88.

This study was performed to investigate the effects of alfuzosin, doxazosin and tamsulosin in vitro on trigone smooth muscle of rabbit. In this study, fifteen rabbits weighing $2.5-3 \mathrm{~kg}$ were used. One strip in the shape of a trigone was prepared for each of the isolated bladders. Firstly, an initial tension of $1 \mathrm{~g}$ was placed on each segment, and we waited for equilibration by constantly bubbling with $95 \% \mathrm{O}_{2}$ and $5 \% \mathrm{CO}_{2}$. Next, the determination level of electrical stimulation which created submaximal contraction and effective dosage were found for trigone and they were determined by applying different concentrations of phenylephrine $\left(10^{-8} \mathrm{M}, 10^{-7} \mathrm{M}\right.$, $\left.10^{-6} \mathrm{M}, 10^{-5} \mathrm{M}\right)$, respectively.

Firstly $10^{-8} \mathrm{M}$ dosage of alfuzosin $\left(10^{-8} \mathrm{M}, 10^{-7} \mathrm{M}, 10^{-6} \mathrm{M}, 10^{-5} \mathrm{M}\right)$ was added, then we waited for $20 \mathrm{~min}$. Then, an effective dosage of phenylephrine $\left(10^{-5} \mathrm{M}\right)$ was added into the solution and we waited for $7 \mathrm{~min}$ again. After this process, electrical stimulation was applied for the contraction of the tissue. After stimulation, the tissue was washed twice every two minutes and rested; we waited until the tissue reached its starting stretching value. The same processes were performed for the other dosages of alfuzosin $\left(10^{-7} \mathrm{M}, 10^{-6} \mathrm{M}, 10^{-5} \mathrm{M}\right)$, doxazosin $\left(10^{-7} \mathrm{M}, 10^{-6} \mathrm{M}, 10^{-5} \mathrm{M}\right)$ and tamsulosin $\left(10^{-7} \mathrm{M}, 10^{-6} \mathrm{M}, 10^{-5} \mathrm{M}\right)$, respectively.

In conclusion, when we compared the amplitudes of the responses of all concentrations of doxazosin, alfuzosin and tamsulosin in the trigone smooth muscle with amplitude of a response of effective concentration of phenylephrine, it was determined that the prevention level of contractions occurred after tamsulosin hydrochloride was higher than after alfuzosin hydrochloride and doxazosin mesylate. With these results, we showed that alfuzosin, doxazosin and tamsulosin inhibited noradrenalin-based contractions in the rabbit trigone smooth muscle and this result can be used both for in vitro and in vivo future studies.
\end{abstract}

Trigone, rabbit, alfuzosin, doxazosin, tamsulosin

Urinary bladder dysfunction secondary to benign prostate hyperplasia $(\mathrm{BPH})$ in humans and animals is a major health problem (Zderic et al. 1996). Nearly $80 \%$ of the human male population will seek medical relief for the symptoms which include urgency, frequency, and nocturia (Girman and Guess 2000). It is apparent that these distressing symptoms are the result of significant changes in the physiology and pharmacology of the obstructed bladder (Zderic et al. 1996). The use of alpha $(\alpha)$ blockers to treat BPH is based on their mechanism of action. BPH causes bladder obstruction by two mechanisms: mechanical compression by the adenoma of the urethra and dynamic obstruction of the bladder by prostate smooth muscle compression. Alpha blockers interrupt motor sympathetic adrenergic nerve supply to the prostate which reduces urethral pressure. Three subtypes of $\alpha$-adrenoceptors, namely, $\alpha_{1 \mathrm{a}}$ and $\alpha_{1 \mathrm{~b}}$ have been cloned over $\alpha_{1 \mathrm{~d}}$ in recent years (Hieble et al. 1995). The existence

Address for correspondence:

A. Karadeniz

University of Atatürk

Department of Physiology, Faculty of Veterinary Medicine

25700 Erzurum, Turkey

Tel.: + 904426314193
Fax: +904426314188
E-mail: karadenizali@gmail.com
http://www.vfu.cz/acta-vet/actavet.htm 
of different $\alpha_{1}$-adrenoceptors in diverse tissues may provide therapeutic opportunity by selectively blocking the desirable subtype in the target tissue without affecting other tissues having other subtypes, thus minimizing the side effects.

Recently, however, attention has been focused on the use of alpha-adrenergic receptor antagonists in patients with this condition. Doxazosin and alfuzosin have been extensively studied and widely used in the treatment of $\mathrm{BPH}$, and tamsulosin is a new drug (Davey 1987; Fulton et al. 1995; Pool 1994; Giuliano et al. 2004). Tamsulosin as a new alpha-adrenergic receptor antagonist has marked antagonistic activity at the numerous alpha-adrenergic receptors present in the smooth muscle within the urinary tract and prostate capsule (O'Leary 2001; Lyseng-Williamson et al. 2002). Thus tamsulosin produces smooth muscle relaxation in these areas and thereby enhances voiding efficiency. In this study, the effects of alfuzosin, doxazosin and tamsulosin of $\alpha_{1}$-adrenergic receptor antagonists on the rabbit bladder trigonal smooth muscle will be examined.

\section{Materials and Methods}

Preparations of trigonal strips

In this study, New Zealand White male rabbits $(2.5-3 \mathrm{~kg})$ were anaesthetized by injection of sodium pentobarbital $\left(40 \mathrm{mg} \cdot \mathrm{kg}^{-1}\right)$ into a marginal ear vein and killed by cervical dislocation. Bladder was surgically removed and put into the Tyrode solution $\left(\mathrm{NaCl} ; 148.9, \mathrm{KCl} ; 2.7, \mathrm{CaCl} ; 1.8, \mathrm{NaPO}_{4} \mathrm{H}_{2} ; 0.2, \mathrm{NaCO}_{3} ; 11.9, \mathrm{MgCl}_{2}\right.$; 1.2, glucose; $5.5 \mathrm{mM}$ ). Then by extracting the trigone, a piece of stripe tissue in the dimension of $5-6 \mathrm{~mm} \times$ $10 \mathrm{~mm}$ was taken. One edge of each trigone tissue preparation was fixed to platinum ring electrodes. The other edge of the tissue was connected to a force transducer and isometric smooth muscle movements were saved via "force transducer" and acquisition system (Biopac MP30 system).

Electrical field stimulation (EFS) and pharmacological responsiveness of trigonal muscles

Trigone samples in organ baths were kept in the Tyrode solution for at least $1 \mathrm{~h}$ prior to the recordings to enable the tissues to adapt to the environment, and the solution was refreshed at 15-min intervals. Then optimal tension relationships were achieved with resting tensions of $1 \mathrm{~g}$ for the trigone strips. Thus, a resting tension of $1 \mathrm{~g}$ was applied to the trigone and the sample was left at $38.5^{\circ} \mathrm{C}$ in the Tyrode solution and constantly bubbled with a mixture of $95 \% \mathrm{O}_{2}$ and $5 \% \mathrm{CO}_{2}$. The isometric smooth muscle activity of the trigone samples was monitored and recorded by computer via the force transducer and an acquisition system (MP30 WSW, Biopac Student Lab PRO Software, Biopac Systems). An EFS device (ISO 150-C, MAY, Commat, Ankara,Turkey) was used for electrical stimulation.

After determining the voltage creating submaximal tissue contraction, the dosage response curve of phenylephrine was designated individually for each trigone. Therefore, six different dosages of pheynlephrine were applied $\left(10^{-9} \mathrm{M}, 10^{-8} \mathrm{M}, 10^{-7} \mathrm{M}, 10^{-6} \mathrm{M}, 10^{-5} \mathrm{M}, 10^{-4} \mathrm{M}\right.$, respectively, $)$ at submaximal voltage and by giving stimulus to the media after $8-10 \mathrm{~min}$, and adding the first $10^{-9} \mathrm{M}$ dosage of phenylephrine. After the application of phenylephrine, by washing the tissue twice every two min, it was allowed to reach its starting stretching value. The other dosages of phenylephrine were put into the media not cumulatively but respectively one by one, and the same process for $10^{-8} \mathrm{M}, 10^{-7} \mathrm{M}, 10^{-6} \mathrm{M}, 10^{-5} \mathrm{M}$ and $10^{-4} \mathrm{M}$ was followed. The phenylephrine-induced maximal contractile responses were calculated as gram for determining the effective dosage.

The effective dosages for each drug were calculated by considering the $\mathrm{C}_{\max }$ value stated for alfuzosin, doxazosin and tamsulosin. These dosages were calculated as $10^{-8} \mathrm{M}, 10^{-7} \mathrm{M}, 10^{-6} \mathrm{M}$ and $10^{-5} \mathrm{M}$ for alfuzosin, $10^{-7} \mathrm{M}, 10^{-6} \mathrm{M}$ and $10^{-5} \mathrm{M}$ for doxazosin, $10^{-7} \mathrm{M}, 10^{-6} \mathrm{M}, 10^{-5} \mathrm{M}$ for tamsulosin. Firstly, $10^{-8} \mathrm{M}$ dosage of alfuzosin was added into both goblets and left for $20 \mathrm{~min}$; later an effective dosage of phenylephrine was added and left for $7 \mathrm{~min}$ (Szell et al. 2000). The contraction of tissue was induced by giving electrical stimulus. Then, tissues were washed twice for the other dosages of alfuzosin $\left(10^{-7} \mathrm{M}, 10^{-6} \mathrm{M}, 10^{-5} \mathrm{M}\right)$. The same processes were followed for dosages of doxazosine $\left(10^{-7} \mathrm{M}, 10^{-6} \mathrm{M}, 10^{-5} \mathrm{M}\right)$ and tamsulosin $\left(10^{-7} \mathrm{M}, 10^{-6}\right.$ $\left.\mathrm{M}, 10^{-5} \mathrm{M}\right)$. The washing process that was done between the applications was followed respectively in the same manner as stated above.

The contraction values that occur as a result of electrical stimulation in the presence of the effective dosage of phenylephrine were accepted as 100\%. By following the same process in the presence of alfuzosin, doxazosin and tamsulosin, the contractions were measured and they were compared with the contractions of the previous application, the prevention ration of drugs' contraction was calculated as percentage.

\section{Statistical analysis}

Data were expressed as the mean \pm standard deviation (S.D.) with a representing number of specimens. The concentration-response curves to various alpha adrenergic antagonists in trigone smooth muscles were analyzed comparatively using the one-way analysis of variance (ANOVA) test; $p<0.05$ was considered. 


\section{Results}

The results of our study are shown in Tables $1-2$ and Figs $1-2$. In the study, it was determined that all concentrations $\left(10^{-9} \mathrm{M}, 10^{-8} \mathrm{M}, 10^{-7} \mathrm{M}, 10^{-6} \mathrm{M}, 10^{-5} \mathrm{M}\right)$ of phenylephrine dose-dependently contracted the smooth muscle of the trigone (Table 1). When compared with the responses of phenylephrine and phenylephrine plus alfuzosin, concentrations decreased by $7 \%$ in $10^{-8} \mathrm{M}$ concentration, $14 \%$ in $10^{-7} \mathrm{M}$ concentration, $20 \%$ in $10^{-6} \mathrm{M}$ concentration and $29 \%$ in $10^{-5} \mathrm{M}$ concentration, respectively; phenylephrine plus doxazosin concentrations decreased respectively by $22 \%$ in $10^{-7} \mathrm{M}$ concentration, $30 \%$ in $10^{-6} \mathrm{M}$ concentration and $38 \%$ in $10^{-5} \mathrm{M}$ concentration; phenylephrine plus tamsulosin concentrations decreased respectively by $31 \%$ in $10^{-7} \mathrm{M}$ concentration, $39 \%$ in $10^{-6} \mathrm{M}$ concentration and $48 \%$ in $10^{-5} \mathrm{M}$ concentration (Table 2, Figs 1, 2). In the present study, it was concluded that contractions of the rabbit trigone smooth muscle could be prevented by alfuzosin less strongly than by the other two antagonists.

Table 1. The amplitude values ( $\mathrm{g}$ ) in the presence of electrical stimulations (EFS) and the various dosages of phenylephrine (PE) in the rabbit bladder trigone smooth muscle $(n=5)$.

\begin{tabular}{|l|c|}
\hline Concentration (M) & Amplitude (g) mean \pm S.D. \\
\hline EFS & $4.86 \pm 0.25^{\mathrm{a}}$ \\
\hline PE $10^{-9} \mathrm{M}+\mathrm{EFS}$ & $5.09 \pm 0.41^{\mathrm{a}}$ \\
\hline PE $10^{-8} \mathrm{M}+\mathrm{EFS}$ & $5.33 \pm 0.38^{\mathrm{b}}$ \\
\hline PE $10^{-7} \mathrm{M}+\mathrm{EFS}$ & $5.55 \pm 0.15^{\mathrm{c}}$ \\
\hline PE $10^{-6} \mathrm{M}+\mathrm{EFS}$ & $5.72 \pm 0.24^{\mathrm{d}}$ \\
\hline PE $10^{-5} \mathrm{M}+\mathrm{EFS}$ & $6.22 \pm 0.35^{\mathrm{e}}$ \\
\hline PE $10^{-4} \mathrm{M}+\mathrm{EFS}$ & $5.62 \pm 0.33^{\text {bcde }}$ \\
\hline
\end{tabular}

$\mathrm{a}, \mathrm{b}, \mathrm{c}, \mathrm{d}, \mathrm{e}, \mathrm{f}$ : Differences between the values involving different letters on the same column are significant $(p<0.05)$.

Table 2. The amplitude values (g) with the application of electrical stimulus (EFS) of the rabbit bladder trigone smooth muscle in the presence of effective phenylephrine only and various concentrations of alfuzosin hydrochloride (Alf), doxazosin mesylate (Dox) and tamsulosin hydrochloride (Tam) $(\mathrm{n}=10)$.

\begin{tabular}{|l|c|c|}
\hline Treatment & Amplitude $(\mathrm{g})$ mean \pm S.D. & Amplitude $(\%)$ \\
\hline PE $10^{-5} \mathrm{M}+\mathrm{EFS}$ & $6.22 \pm 0.85^{\mathrm{b}}$ & 100 \\
\hline Alf $10^{-8} \mathrm{M}+\mathrm{EFS}$ & $5.77 \pm 0.79^{\mathrm{ab}}$ & 92.76 \\
\hline Alf $10^{-7} \mathrm{M}+\mathrm{EFS}$ & $5.35 \pm 0.76^{\mathrm{ab}}$ & 86.01 \\
\hline Alf $10^{-6} \mathrm{M}+\mathrm{EFS}$ & $4.99 \pm 0.77^{\mathrm{ab}}$ & 80.23 \\
\hline Alf $10^{-5} \mathrm{M}+\mathrm{EFS}$ & $4.43 \pm 0.70^{\mathrm{ab}}$ & 71.22 \\
\hline Dox $10^{-7} \mathrm{M}+\mathrm{EFS}$ & $4.89 \pm 0.79^{\mathrm{ab}}$ & 78.62 \\
\hline Dox $10^{-6} \mathrm{M}+\mathrm{EFS}$ & $4.37 \pm 0.80^{\mathrm{ab}}$ & 70.26 \\
\hline Dox $10^{-5} \mathrm{M}+\mathrm{EFS}$ & $3.88 \pm 0.79^{\mathrm{ab}}$ & 62.38 \\
\hline Tam $10^{-7} \mathrm{M}+\mathrm{EFS}$ & $4.35 \pm 0.82^{\mathrm{ab}}$ & 69.94 \\
\hline Tam $10^{-6} \mathrm{M}+\mathrm{EFS}$ & $3.82 \pm 0.82^{\mathrm{ab}}$ & 61.41 \\
\hline Tam $10^{-5} \mathrm{M}+\mathrm{EFS}$ & $3.26 \pm 0.80^{\mathrm{a}}$ & 52.41 \\
\hline
\end{tabular}

$\mathrm{a}, \mathrm{b}$ : Differences between the values with different letters in the same column are significant $(p<0.05)$.

\section{Discussion}

In this study, comparison of relaxation responses of the rabbit bladder trigone smooth muscle influenced by alpha adrenergic antagonist drugs, alfuzosin hydrochloride, doxazosin mesylate and tamsulosin hydrochloride were researched. Alpha -adrenergic $^{-}$ receptor regulation of prostatic smooth muscle contraction was initially defined by Caine et al. (1975) and Raz et al. (1973) through isometric tension studies of prostate tissue in the presence of noradrenalin. At the end of studies conducted for many years, tamsulosin of alpha adrenergic receptor antagonist with selective pharmacological features that was effective for $\alpha_{1 a}$ adrenergic receptors densely present in the prostate tissue was developed (O'Leary 2001). Lyseng-Williamson et al. (2002) stated that the average selectiveness feature for tamsulosin's $\alpha_{1 a}{ }^{-}$ adrenergic receptor was 3.9 - 38 times higher when compared with $\alpha_{1 b}$, and 3 - 20 times higher when compared with $\alpha_{1 \mathrm{~d}}$. Because of tamsulosin's high affinity for receptors, it caused fewer side effects when compared with the other alpha adrenergic antagonists such as doxazosin, terazosin, prazosin and alfuzosin. Doxazosin mesylate and alfuzosin hydrochloride did not show the selective features 


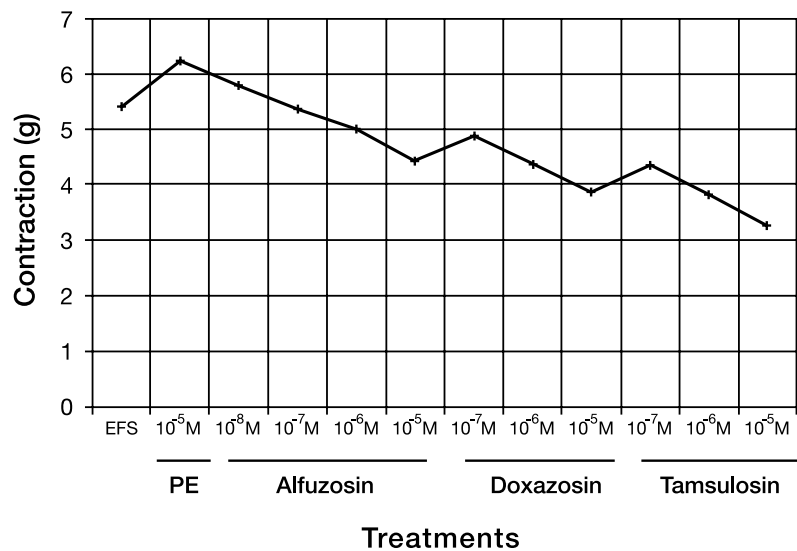

Fig. 1. The amplitude values (g) with the application of electrical stimulus (EFS) of the rabbit bladder trigone smooth muscle in the prsence of effective phenylephrine (PE) only and various concentrations of alfuzosin hydrochloride, daxazosin mesylate and tamsulosin hydrochloride $(\mathrm{n}=10)$.

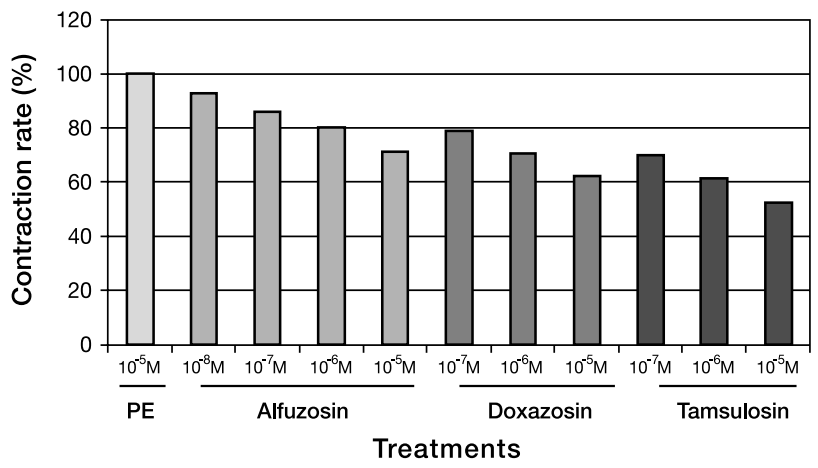

Fig. 2. The amplitude values (\%) with the application of electrical stimulus of the rabbit bladder trigone smooth muscle in the prsence of effective phenylephrine (PE) only and various concentrations of alfuzosin hydrochloride, daxazosin mesylate and tamsulosin hydrochloride $(\mathrm{n}=10)$. $10^{-5} \mathrm{M}$ (Karadeniz and Pişkin 2006) for rat the trigone, and $10^{-2} \mathrm{M}$ (Noble et al. 1997) for human prostate tissue. The reason for the difference between effective concentrations of phenylephrine can be due to the density and distribution of adrenergic receptors in the tissues and it may vary in different organs and types.

Alfuzosin is selective for $\alpha_{1}$ receptors versus $\alpha_{2}$-adrenoceptors but without $\alpha_{1}$ subtype selectivity (Davey 1987). There are many studies related to alfuzosin hydrochloride in vivo and in vitro. Giuliano et al. (2004) stated that alfuzosin given intravenously to rats block contractions occurring on smooth muscle of seminal vesicle and bladder neck. In a cat model, the elevated urethral pressure which occurs via sympathetic nerve stimulation or infusion of phenylephrine was significantly inhibited by alfuzosin, while no sustained elevation of blood pressure was observed. In comparison to prazosin and terazosin, it exerted the highest selectivity for the lower urinary tract (Mátyus and Horváth 1997). 
De Reijke and Klarskov (2004) stated that improving symptoms belonging to prostate patients who use alfuzosin are lower in comparison to doxazosin. Palea and Barras (2003) determined that contractions occurring in the rabbit corpus cavernous were blocked by alfuzosin. Lefevre-Borg et al. (1993) informed that contractions induced by phenylephrine in the rabbit trigone smooth muscle and urethra were blocked by prazosin at an equal rate, whereas alfuzosin strongly decreased urethra contractions when compared with the trigone. The amplitudes of contractions caused by electrical stimulation in the presence of phenylephrine plus alfuzosin $\left(10^{-8} \mathrm{M}, 10^{-7} \mathrm{M}, 10^{-6} \mathrm{M}, 10^{-5} \mathrm{M}\right)$ were numerically lower than phenylephrine treatment alone (Fig. 1, Table 2).

In our study, we showed that the responses of only phenylephrine treatments compared with the responses of phenylephrine plus alfuzosin significantly decreased by $7 \%$ at a $10^{-8}$ $\mathrm{M}$ concentration, $14 \%$ at a $10^{-7} \mathrm{M}$ concentration, $20 \%$ at a $10^{-6} \mathrm{M}$ concentration and $29 \%$ at a $10^{-5} \mathrm{M}$ concentration, respectively. It was concluded that contractions occurring in the rabbit trigone smooth muscle could be less strongly prevented by alfuzosin than by the other two antagonists. This result may be due to the non-selective feature of alfuzosin for alpha adrenergic receptors in the rabbit trigone.

Subtype non-selective $\alpha_{1}$-adrenoceptor antagonist such as doxazosin which was originally developed for hypertension has been used for the treatment of BPF. This agent was shown to be effective, but it may cause orthostatic hypotension because of the existence of $\alpha_{1}$-adrenoceptors in the vasculature (Chapple 1994). Alabaster and Davey (1986) and Davey (1987) stated in the studies done on the isolated aortic ring of rabbit, brain membranes and venues of dogs that affinity of doxazosin for $\alpha_{1}$-adrenergic receptors was higher than its affinity for $\alpha_{2}$-adrenergic receptors. Also in vivo studies concluded that blood pressure and contractions of the rat bladder decreased as a result of giving doxazosin intraspinally to rats (Yoshiyama et al. 2000; Jeong and Lee 2000), intravenously to cats (Ramage and Wyllie 1995) and dogs. This proved that doxazosin has an antagonist effect for $\alpha_{1}$-adrenergic receptors.

The amplitudes of contractions caused by electrical stimulation of phenylephrine plus doxazosin $\left(10^{-7} \mathrm{M}, 10^{-6} \mathrm{M}, 10^{-5} \mathrm{M}\right)$ were numerically lower $(p<0.05)$ than phenylephrine treatment alone (Fig. 1 and Table 2). This fact showed that all concentrations of doxazosin dose-dependently inhibited the contractions originating from noradrenalin in the rabbit trigone smooth muscle. In the study, when compared with the only effective dosage of phenylephrine, the responses taken to phenylephrine in the presence of all concentrations of doxazosin decreased by $22 \%$ in $10^{-7} \mathrm{M}$ concentration, $30 \%$ in $10^{-6} \mathrm{M}$ concentration and $38 \%$ in $10^{-5} \mathrm{M}$ concentration, respectively. This result showed that contractions occurring as a result of the action of phenylephrine in the rabbit trigone smooth muscle and $\alpha$ adrenergic receptors could be prevented by the increase in density of doxazosin. Seo et al. (1999) stated that $10 \%$ the inhibition ratio of contraction were induced by doxazosin in rabbit trigone and cavernous tissues. At the same time Koç (2001) informed that doxazosin had a pressing effect on the contractions occurring after noradrenalin in the rat vas deferens, seminal vesicle and epididymis smooth muscles. These findings proved that doxazosin had an $\alpha_{1}$ adrenergic receptor antagonist effect. This result suggested that $\alpha_{1 \mathrm{a}}$ adrenergic receptors at rabbit bladder trigone smooth muscle could be prevented by doxazosin; therefore the flow of urine could be eased by loosening the neck part of the bladder.

Tamsulosin, a phenylethylamine type a-blocker, has a high affinity for alpha-1 adrenoceptor with moderate selectivity. This selectivity is also preserved for its metabolites indicating that it is encoded to the phenoxy ring moiety (Lyseng-Williamson et al. 2002). In the study, when compared with the responses of the only usage of phenylephrine, contractions occurring after phenylephrine in the presence of all contentrations starting from the lowest concentration of tamsulosin decreased by $31 \%$ in $10^{-7} \mathrm{M}$ concentration, $39 \%$ in $10^{-6} \mathrm{M}$ concentration and $48 \%$ in $10^{-5} \mathrm{M}$ concentration, respectively. This showed 
that contractions occurred as a result of the action of phenylephrine on the $\alpha_{1}$ adrenergic receptors in the rabbit trigone smooth muscle, and the contractions could be prevented by increasing the concentration of tamsulosin. This fact indicated that tamsulosin dosedependently inhibited the contractions caused by noradrenalin in the rabbit bladder trigone smooth muscle $(p<0.05)$ (Fig. 1 and Table 2).

Some researchers found that the contractions of in vivo dog (Breslin et al. 1993; Kenny et al. 1994; Kontani and Shiraoya 2002 and in vitro rat (Tang et al. 2004) prostate smooth muscle induced by epinephrine and phenylephrine could be prevented by tamsulosin. Moreover, the contractions occurring due to phenylephrine in the human prostate smooth muscle could be blocked by tamsulosin (Bouchelouche et al. 2005; Harada and Fujimura (2000), and tamsulosin is used in the treatment of illnesses related to the human prostate and lower urinary tracts (Kawachi 1998; Akduman and Crawford 2001; Schulman et al. 2001; Kirby 2003).

Some researchers stated that the contractions occurring after phenylephrine in the dog bladder could be prevented by tamsulosin competitively (Testa et al. 1997; Minneman et al. 1988; Leonardi et al. 1997; Witte et al. 2002); furthermore, the effects of tamsulosin on the amplitude and frequency of contractions in the rat bladder was low (Sudoh et al. 1997). In previous studies, contractions of the rat tail (Lachnit et al. 1997; Jähnichen et al. 2004) and mesenteric artery (Van Der Graaf et al. 1996) induced by phenylephrine or noradrenalin were more strongly prevented by tamsulosin than by other alpha adrenergic antagonists, such as prazosin, phentholamin, WB-401, 5 methil-urapidil, spiperone and HV 723.

Seo et al. (1999) informed that tamsulosin prevented the contractions occurring after phenylephrine in the rabbit cavernous smooth muscle $1000 \times$ more than doxazosin and terazosin. These authors found $81 \%$ inhibition induced by tamsulosin in the rabbit trigone smooth muscle. Our result is similar to the above finding, with contractions decreased only by $48 \%$. This may be due to the density of receptors in tissues or differences between species.

In this study, as a result of stimulating adrenergic receptors by phenylephrine we found that tamsulosin could prevent the contractions occurring in the trigone area more strongly than alfuzosin and doxazosin, as a result of the selective affinity of tamsulosin for $\alpha_{1 \text { a }}$ adrenergic receptors. Potentially, tamsulosin may allow the control of benign prostate hyperplasia with its minimal adverse effect on other alpha-adrenergic receptors (e.g., low potential for interfering with blood pressure control, vasodilatation).

Our experiment comparing the effect of relatively selective (tamsulosin) and non-selective (alfuzosin and doxazosin) alpha-1 adrenergic receptor antagonists on relaxation of the rabbit trigonal smooth muscle demonstrated that tamsulosin was the most effective drug. Therefore, alfuzosin hydrochloride, doxazosin mesylate and tamsulosin hydrochloride could provide an easy flow of urine by inhibition of alpha adrenergic receptors in cat and dog diseases; however, it was decided that these effects must be supported by clinical studies.

\section{Účinek alfa -adrenergních antagonistů (alfuzosin, doxazosin a tamsulosin) na relaxaci hladkého svalu z trigonum vesicae králíka}

Autoři zkoumali vliv alfuzosinu, doxazosinu a tamsulosinu in vitro na hladký sval z trigonum vesicae králíka. V pokusech bylo použito 15 králíků o hmotnosti 2,5-3 kg. Z každého izolovaného močového měchýř byl odpreparován proužek svalu ve tvaru trigona. Každý segment byl zpočátku vystaven tahu $1 \mathrm{~g}$ a za stálého probublávání $95 \% \mathrm{O}_{2}$ a $5 \% \mathrm{CO}_{2}$ bylo dosaženo rovnováhy svalové tense. Poté byla stanovena intenzita elektrická stimulace, která vyvolala submaximální svalovou kontrakci, a aplikací různých koncentrací fenylefrinu (postupně $10^{-8} \mathrm{M}, 10^{-7} \mathrm{M}, 10^{-6} \mathrm{M}, 10^{-5} \mathrm{M}$ ) byly stanoveny jeho účinné dávky pro zkoumané trigony. 
Poté byla aplikována $10^{-8} \mathrm{M}$ dávka alfuzosinu, po $20 \mathrm{~min}$ byla do roztoku přidána účinná dávka fenylefrinu $\left(10^{-5} \mathrm{M}\right)$. Po dalších 7 min byl aplikován elektrický stimul, který vyvolal svalovou kontrakci. Po provedení stimulace byla tkán̆ dvakrát propláchnuta $\mathrm{v}$ intervalu 2 min a ponechána $\mathrm{v}$ klidu, dokud se nevrátila do původního stavu. Proces byl postupně opakován i s ostatními dávkami alfuzosinu $\left(10^{-7} \mathrm{M}, 10^{-6} \mathrm{M}, 10^{-5} \mathrm{M}\right)$, doxazosinu $\left(10^{-7} \mathrm{M}\right.$, $\left.10^{-6} \mathrm{M}, 10^{-5} \mathrm{M}\right)$ a tamsulosinu $\left(10^{-7} \mathrm{M}, 10^{-6} \mathrm{M}, 10^{-5} \mathrm{M}\right)$.

Srovnání amplitud odezvy na všechny použité koncentrace doxazosinu, alfuzosinu a tamsulosinu na hladký sval trigonum vesicae s amplitudou odezvy účinné koncentrace fenylefrinu, vedlo k zjištění, že kontraktilita byla po podání tamsulosin hydrochloridu vyšší než po podání alfuzosin hydrochloridu a doxazosin mesylátu. Bylo tak prokázáno, že alfuzosin, doxazosin a tamsulosin inhibují kontrakce vyvolané účinkem noradrenalinu na hladký sval trigonum vesicae králíka. Výsledky studie lze využít pro další studie jak in vitro, tak in vivo.

\section{Acknowledgement}

The authors are indebted to anonymous reviewers for valuable suggestions on the manuscript.

\section{References}

AKDUMAN B, CRAWFORD ED 2001: Terazosin, doxazosin, and prazosin: current clinical experience. Urology 58: $49-54$

ALABASTER VA, DAVEY MJ 1986: The alpha 1-adrenoceptor antagonist profile of doxazosin: preclinical pharmacology. Br J Clin Pharmacol 21(Suppl.): 9S-17S

BOUCHELOUCHE K, ANDERSEN L, ALVAREZ S, NORDLING J, BOUCHELOUCHE P 2005: Increased contractile response to phenylephrine in detrusor of patients with bladder outlet obstruction: effect of the alpha1A and alpha1D-adrenergic receptor antagonist tamsulosin. J Urol 173: 657-661

BRESLIN D, FIELDS DW, CHOU TC, MARION DN, KANE M, VAUGHAN ED JR, FELSEN D 1993: Medical management of benign prostatic hyperplasia: a canine model comparing the in vivo efficacy of alpha-1 adrenergic antagonists in the prostate. J Urol 149: 395-399

CAINE M, RAZ S, ZEIGLER M 1975: Adrenergic and cholinergic receptors in the human prostate, prostatic capsule and bladder neck. Br J Urol 47: 193-202

CHAPPLE CR, BURT RP, ANDERSSON PO, GREENGRASS P, WYLLIE M, MARSHALL I 1994: Alpha1adrenoceptor subtypes in the human prostate. Br J Urol 74: 585-589

DAVEY M 1987: Mechanism of alpha blockade for blood pressure control. Am J Cardiol 59: 18G-28G

DE REIJKE TM, KLARSKOV P 2004: Comparative efficacy of two alpha-adrenoreceptor antagonists, doxazosin and alfuzosin, in patients with lower urinary tract symptoms from benign prostatic enlargement. BJU Int 93: $757-762$

FULTON B, WAGSTAFF AJ, SORKIN EM 1995: Doxazosin. An update of its clinical pharmacology and therapeutic applications in hypertension and benign prostatic hyperplasia. Drugs 49: 295-320

GIRMAN CJ, GUESS HA 2000: Epidemiology of benign prostatic hyperplasia. In: LEPOR H, (Ed.): Prostatic diseases. Philadelphia, W.B. Saunders Co., pp. 116-126

GIULIANO F, BERNABE J, DROUPY S, ALEXANDRE L, ALLARD J 2004: A comparison of the effects of tamsulosin and alfuzosin on neurally evoked increases in bladder neck and seminal vesicle pressure in rats. BJU Int 93: 605-608

HARADA K, FUJIMURA A 2000: A. Clinical pharmacology of alpha1A selective and nonselective alpha1blockers. BJU Int 86: 31-34; discussion pp. 34-35

HIEBLE JP, BYLUND DB, CLARKE DE, EIKENBURG DC, LANGER SZ, LEFKOWITZ RJ, MINNEMAN KP, RUFFOLO RR JR 1995: International Union of Pharmacology. X. Recommendation for nomenclature of alpha 1-adrenoceptors: consensus update. Pharmacol Rev 47: 267-270

JÄHNICHEN S, ELTZE M, PERTZ HH 2004: Evidence that $\alpha_{1 \mathrm{~B}}$-adrenoceptors are involved in noradrenalineinduced contractions of rat tail artery. Eur J Pharmacol 488: 157-167

JEONG MS, LEE JG 2000: The role of spinal and peripheral alpha1- and alpha2-adrenoceptors on bladder activity induced by bladder distension in anaesthetized rat. BJU Int 85: 925-31

KARADENIZ A, PISKIN I 2006: The effects of some alpha-1 adrenergic antagonist on trigone smooth muscle of rat bladder. J Anim Vet Adv 5: 1223-1228

KATSUNARI T, MINORI S, SHUICHI S, MASAHARU A, MARTIN CM 1997: Effects of Tamsulosin Metabolites at Alpha-1 Adrenoceptor Subtypes. J Pharmacol Exp Ther 280: 1-5

KAWACHI Y 1998: Effect of Tamsulosin on urodynamics in benign prostatic hypertrophy. Current Therap Res. 59: $149-161$

KENNY BA, NAYLOR AM, CARTER AJ, READ AM, GREENGRASS PM, WYLLIE MG 1994: Effect of alpha 1 adrenoceptor antagonists on prostatic pressure and blood pressure in the anesthetized dog. Urology 44: $52-57$ 
KIRBY RS 2003: A randomized, double-blind crossover study of tamsulosin and controlled-release doxazosin in patients with benign prostatic hyperplasia. BJU Int 91: 41-44

KOÇ F 2001: [The effects of prazosine and doxazosine on in vitro smooth muscle contraction of rat vas deferens, epididymis and seminal vesicae] Rat vasa deferens, epididim ve seminal keselerin in vitro kasılma yanıtlarına prazosin ve doxazosinin etkileri [in Turkish]. Master Thesis. No: 108007. Department of Urology, Faculty of Medicine, University of Ondokuz Mayıs.

KONTANI H, SHIRAOYA C 2002: Method for simultaneous recording of the prostatic contractile and urethral pressure responses in anesthetized rats and the effects of tamsulosin. Jpn J Pharmacol 90: 281-290

LACHNIT WG, TRAN AM, CLARKE DE, FORD AP 1997: Pharmacological characterization of an alpha 1A-adrenoceptor mediating contractile responses to noradrenaline in isolated caudal artery of rat. $\mathrm{Br} \mathrm{J}$ Pharmacol 120: 819-826

LEFEVRE-BORG F, O'CONNOR SE, SCHOEMAKER H, HICKS PE, LECHAIRE J, GAUTIER E, PIERRE F, PIMOULE C, MANOURY P, LANGER SZ 1993: Alfuzosin, a selective alpha 1-adrenoceptor antagonist in the lower urinary tract. Br J Pharmacol 109: 1282-1289

LEONARDI A, HIEBLE JP, GUARNERI L, NASELSKY DP, POGGESI E, SIRONI G, SULPIZIO AC, TESTA R 1997: Pharmacological characterization of the uroselective alpha-1 antagonist Rec 15/2739 (SB 216469): role of the alpha-1L adrenoceptor in tissue selectivity, part I. J Pharmacol Exp Ther 281: 1272-1283

LYSENG-WILLIAMSON KA, JARVIS B, WAGSTAFF AJ 2002: Tamsulosin: an update of its role in the management of lower urinary tract symptoms. Drugs 62: 135-167

MÁTYUS P, HORVÁTH K 1997: Alfa-adrenergic approach in the medical management of benign prostatic hyperplasia. Med Res Rev 17: 523-535

MINNEMAN KP, HAN C, ABEL PW 1988: Comparison of alpha 1-adrenergic receptor subtypes distinguished by chlorethylclonidine and WB 4101. Mol Pharmacol 33: 509-514

NOBLE AJ, CHESS-WILLIAMS R, COULDWELL C, FURUKAWA K, UCHYIUMA T, KORSTANJE C, CHAPPLE CR 1997: The effects of tamsulosin, a high affinity antagonist at functional alpha 1A- and alpha 1D-adrenoceptor subtypes. Br J Pharmacol 120: 231-238

O’LEARY MP 2001: Tamsulosin: current clinical experience. Urology 58: 42-48; discussion 48

PALEA S, BARRAS M. 2003: Comparison of the relaxant effects of alfuzosin, phentolamine and sildenafil on rabbit isolated corpus cavernosum. BJU Int 91: 873-877

POOL JL 1994: Effects of doxazosin on coronary heart disease risk factors in the hypertensive patient. Br J Clin Pract Suppl 74: 8-12

RAMAGE AG, WYLLIE MG 1995: A comparison of the effects of doxazosin and terazosin on the spontaneous sympathetic drive to the bladder and related organs in anaesthetized cats. Eur J Pharmacol 294: 645-650

RAZ S, ZEIGLER M, CAINE M 1973: Pharmacological receptors in the prostate. Br J Urol 27: 663-667

SCHULMAN CC, LOCK TM, BUZELIN JM, BOEMINGHAUS F, STEPHENSON TP, TALJA M 2001: European Tamsulosin Study Group. Long-term use of tamsulosin to treat lower urinary tract symptoms/benign prostatic hyperplasia. J Urol 166: 1358-1363

SEO KK, LEE MY, LIM SW, KIM SC 1999: Comparison of relaxation responses of cavernous and trigonal smooth muscles from rabbits by alpha1-adrenoceptor antagonists; prazosin, terazosin, doxazosin, and tamsulosin. J Korean Med Sci 14: 69-74

SUDOH K, INAGAKI O, TAKENAKA T 1997: Effect of alpha 1-adrenoceptor antagonists on urinary bladder function in urethane-anesthetized rats. Gen Pharmacol 28: 521-524

SZELL EA, YAMAMOTO T, DE GROAT WC, SOMOGYI GT 2000: Smooth muscle and parasympathetic nerve terminals in the rat urinary bladder have different subtypes of alpha (1) adrenoceptors. Br J Pharmacol 130: 1685-1691

TANG LM, CHENG JT, TONG YC 2004: Inhibitory effect of buflomedil on prostate alpha1A adrenoceptor in the Wistar rat. Neurosci Lett 367: 224-227

TESTA R, GUARNERI L, ANGELICO P, POGGESI E, TADDE C, SIRONI G, COLOMBO D, SULPIZIO AC, NASELSKY DP, HIEBLE JP, LEONARDI A 1997: Pharmacological characterization of the uroselective alpha-1 antagonist Rec 15/2739 (SB 216469): role of the alpha-1L adrenoceptor in tissue selectivity, part II. J Pharmacol Exp Ther. 281: 1284-1293

VAN DER GRAAF PH, SHANKLEY NP, BLACK JW 1996: Analysis of the activity of alpha 1-adrenoceptor antagonists in rat aorta. Br J Pharmacol 118: 299-310

WITTE DG, BRUNE ME, KATWALA SP, MILICIC I, STOLARIK D, HUI YH, MARSH KC, KERWIN JF JR, MEYER MD, HANCOCK AA 2002: Modeling of relationships between pharmacokinetics and blockade of agonist-induced elevation of intraurethral pressure and mean arterial pressure in conscious dogs treated with alpha(1)-adrenoceptor antagonists. J Pharmacol Exp Ther 300: 495-504

YOSHIYAMA M, YAMAMOTO T, DE GROAT WC 2000: Role of spinal alpha (1)-adrenergic mechanisms in the control of lower urinary tract in the rat. Brain Res 882: 36-44

ZDERIC SA, LEVIN RM, WEIN AJ 1996: Voiding function: relevant anatomy physiology, pharmacology and molecular biology. In: GILLENWATER JY, GRAYHACK JT, HOWARDS SS, DUCKETT JD (Eds): Adult and pediatric urology. $3^{\text {rd }}$ ed. Chicago. Mosby YearBook Inc., pp. 1159-219 